\title{
COVID-19 Vaccine Hesitancy-A Scoping Review of Literature in High-Income Countries
}

\author{
Junjie Aw ${ }^{1, *,+}$, Jun Jie Benjamin Seng ${ }^{2,+}$, Sharna Si Ying Seah ${ }^{1}$ and Lian Leng Low ${ }^{1,2,3,4,5}$ \\ 1 Outram Community Hospital, SingHealth Community Hospitals, 10 Hospital Boulevard, \\ Singapore 168582, Singapore; sharna.seah.s.y@singhealthch.com.sg (S.S.Y.S.); \\ low.lian.leng@singhealth.com.sg (L.L.L.) \\ 2 MOH Holdings Pte Ltd., 1 Maritime Square, Singapore 099253, Singapore; benjamin.seng@u.duke.nus.edu \\ 3 Department of Family Medicine and Continuing Care, Singapore General Hospital, Singapore, Outram Rd, \\ Singapore 169608, Singapore \\ 4 SingHealth Duke-NUS Family Medicine Academic Clinical Program, Outram Rd, \\ Singapore 169608, Singapore \\ 5 SingHealth Regional Health System PULSES Centre, Singapore Health Services, Outram Rd, \\ Singapore 169608, Singapore \\ * Correspondence: aw.junjie@singhealth.com.sg \\ + Co-first authors.
}

check for updates

Citation: Aw, J.; Seng, J.J.B.; Seah, S.S.Y.; Low, L.L. COVID-19 Vaccine Hesitancy-A Scoping Review of Literature in High-Income Countries. Vaccines 2021, 9, 900. https:/ / doi.org/10.3390/vaccines 9080900

Academic Editors: Barbara Rath and Ger Rijkers

Received: 11 June 2021

Accepted: 10 August 2021

Published: 13 August 2021

Publisher's Note: MDPI stays neutral with regard to jurisdictional claims in published maps and institutional affiliations.

Copyright: (c) 2021 by the authors. Licensee MDPI, Basel, Switzerland. This article is an open access article distributed under the terms and conditions of the Creative Commons Attribution (CC BY) license (https:// creativecommons.org/licenses/by/ $4.0 /)$.

\begin{abstract}
Vaccine hesitancy forms a critical barrier to the uptake of COVID-19 vaccine in highincome countries or regions. This review aims to summarize rates of COVID-19 hesitancy and its determinants in high-income countries or regions. A scoping review was conducted in Medline ${ }^{\circledR}$, Embase $^{\circledR}, \mathrm{CINAHL}^{\circledR}$, and Scopus ${ }^{\circledR}$ and was reported in accordance with the PRISMA-SCr checklist. The search was current as of March 2021. Studies which evaluated COVID-19 vaccine hesitancy and its determinants in high-income countries (US\$12,536 or more GNI per capita in 2019) were included. Studies conducted in low, lower-middle, and upper-middle income countries or regions were excluded. Factors associated with vaccine hesitancy were grouped into four themes (vaccine specific, individual, group, or contextual related factors). Of 2237 articles retrieved, 97 articles were included in this review. Most studies were conducted in U.S. $(n=39)$ and Italy $(n=9)$. The rates of vaccine hesitancy across high-income countries or regions ranged from 7-77.9\%. 46 studies (47.4\%) had rates of $30 \%$ and more. Younger age, females, not being of white ethnicity and lower education were common contextual factors associated with increased vaccine hesitancy. Lack of recent history of influenza vaccination, lower self-perceived risk of contracting COVID-19, lesser fear of COVID19 , believing that COVID-19 is not severe and not having chronic medical conditions were most frequently studied individual/group factors associated with increased vaccine hesitancy. Common vaccine-specific factors associated with increased vaccine hesitancy included beliefs that vaccine are not safe/effective and increased concerns about rapid development of COVID-19 vaccines. Given the heterogeneity in vaccine hesitancy definitions used across studies, there is a need for standardization in its assessment. This review has summarized COVID-19 vaccine hesitancy determinants that national policymakers can use when formulating health policies related to COVID-19 vaccination.
\end{abstract}

Keywords: scoping review; coronavirus disease-19 (COVID-19); COVID-19 pandemic; SARS-CoV-2 infection; 2019 novel coronavirus disease; vaccines; COVID-19 vaccines; vaccine hesitancy; vaccine acceptance

\section{Introduction}

Since its first reported case in December 2019, the coronavirus-2019 (COVID-19) pandemic has culminated in nearly 179 million infections and 3.88 million deaths globally as of 24 June 2021 [1]. Lockdowns, social distancing measures, and movement restrictions were implemented as a result to abate the spread of infection worldwide [2]. The aftermath of the pandemic has negatively affected global economies. For example, the Internal Labor 
Organization has estimated 25 million jobs to be lost and the United Nations World Tourism Organization has estimated a loss of US $\$ 80$ billion dollars in international travel receipts internationally in 2020 [3,4].

Vaccination forms a critical pillar in the road to recovery from the COVID-19 pandemic [5]. Notably, vaccine candidates with promising results received expeditious emergency use authorization by drug authorities. Despite quick and concerted vaccination programs implemented by governments globally, such efforts have been hampered by vaccine hesitancy. Vaccine hesitancy was identified by the World Health Organization as one of the 10 threats to global health in 2019. It is defined as the "delay in acceptance or refusal of vaccination despite availability of vaccination services" by the Strategic Advisory Group of Experts on immunization and involves a complex interaction of time, place, context, and vaccine specific factors [6].

Among non-high income countries or regions, results from the 2018 Wellcome Global monitor survey showed that vaccines were widely accepted [7,8], in contrast to high-income countries (defined by World Bank as countries having a 2019 Gross National Income (GNI) per capita of US $\$ 12,536$ and more) [9]. A recent study by Arce et al. showed that the average willingness to take COVID-19 vaccine was higher in the populace from non-high income countries or regions such as Nepal (97\%) as compared to those in high-income countries or regions such as United States (6\%) [10]. Similar findings were noted in a study by Sallam et al. [11].

In view of the importance of COVID-19 vaccine hesitancy, we aim to perform a scoping review to evaluate COVID-19 vaccine hesitancy and its determinants among high-income countries or regions. We hope that our results will aid healthcare administrators and policymakers in understanding COVID-19 vaccine hesitancy determinants in high-income countries or regions. This will, in turn, aid and facilitate the planning of vaccination campaigns to enhance uptake of COVID-19 vaccinations.

\section{Methodology}

We conducted a scoping review on studies which evaluated COVID-19 vaccine hesitancy in high-income countries or regions. This review was reported using the Preferred Reporting Items for Systematic review and Meta-Analysis extension for Scoping Reviews (PRISMA-ScR) checklist [12].

\subsection{Protocol and Registration}

The protocol for this scoping review is registered on 11 April 2021 on Open Science Framework (Available online: https:/ / osf.io/3n7yv (accessed on 11 April 2021)).

\subsection{Eligibility Criteria and Information Sources}

A literature search was performed in four major literature databases which were namely: Medline ${ }^{\circledR}$, Embase $^{\circledR}$, CINAHL $^{\circledR}$, and Scopus ${ }^{\circledR}$. Full-text articles in English language which evaluated COVID-19 hesitancy rates and the associated determinants in high-income countries or regions were included. Study designs in this review included randomized controlled trials, observational studies, cross-sectional studies, cohort studies and qualitative studies. We excluded studies that were performed in non-high-income countries (GNI per capita < US\$12,535). Commentaries, editorials, letters and correspondences without original data as well as irrelevant systematic reviews and meta-analyses were excluded. The search period for the review spanned between December 2019 and March 2021. Institutional review board approval was exempted for this review as it did not involve human subjects.

\subsection{Search Strategy}

The search strategy comprised of two main themes which were COVID-19 vaccine and vaccine hesitancy. The search strategy used was adapted from prior systematic reviews 
which evaluated vaccine hesitancy related to other vaccines [13-15]. The full details of the search strategy is available from Supplementary File Table S1.

\subsection{Selection of Sources of Evidence, Data Charting Process, and Data Items}

Citations retrieved from the four databases were exported into Endnote Software Online (Clarivate Analytics, Philadelphia, PA, USA). Duplicated citations were removed prior to screening of articles. Two independent reviewers (J Aw and JJB Seng performed the initial pilot exercise for the screening of the first 200 records (based on title and abstract). Thereafter, the titles and abstracts of all retrieved articles from the four databases were screened by the same reviewers independently. The full-text articles of potentially relevant articles were evaluated prior to inclusion in this review. All disagreements in the inclusion phase of the review were discussed to reach a consensus. For discrepancies which could not be resolved between the two reviewers, arbitration was made with a third independent reviewer (SYS SEAH).

To chart data from the included articles, a standardized Microsoft Excel data collection sheet was used. This information included the name of author, title of study, publication year, sample size, study design and methodology, characteristics of patient population, tools used to evaluate COVID-19 vaccine hesitancy, reported hesitancy rates, and determinants associated with increased COVID-19 vaccine hesitancy.

\subsection{Critical Appraisal of Individual Sources of Evidence}

The risk of bias appraisal for included studies was not performed as this was not the objective of this scoping review.

\subsection{Summary and Synthesis of Results}

Descriptive statistics were used to summarize the characteristics of studies included in this review. Vaccine hesitancy rate was reported from individual study according to the definition described in each study. In studies which reported only vaccine acceptance rates, vaccine hesitancy rates were computed using the formula: [100 (\%) — vaccine acceptance rates (\%)]. In cohort studies which reported longitudinal rates of vaccine hesitancy, the mean vaccine hesitancy rates were extracted. Other variables collected included the study design and methodology, characteristics of participants and determinants of COVID-19 vaccine hesitancy. Graphical charts and tables were used to present the results.

There is no widely accepted definition for cut-off with regards to a high vaccine hesitancy rate. Assuming COVID-19 vaccines can stop transmissibility and that COVID-19 has a $R_{0}$ of $2-3.5$, a $60-70 \%$ vaccination uptake is estimated for herd immunity [16]. We therefore define high vaccine hesitancy as 30 or more percent in this review.

A narrative summary of factors associated with increased COVID-19 vaccine hesitancy was presented. The determinants of vaccine related hesitancy were grouped into three main categories: contextual influences, individual/group influences, and vaccine/vaccination specific issues, as proposed by the Strategic Advisory Group of Experts (SAGE) on immunization [6,17]. These determinants were reported as per described in individual studies.

A framework diagram was used to summarize the most frequently studied determinants of COVID-19 vaccine hesitancy in high-income countries or regions.

\subsection{Data Availability Statement}

Data analyzed in the study is included in the published article and Supplementary File Tables S1 and S2.

\section{Results}

A flowchart for inclusion of articles in this review is illustrated and of 2237 citations retrieved, a total of 97 articles were included based on the inclusion criteria (Figure 1). The percentage of agreement between the reviewers during the inclusion was $90.7 \%$. 


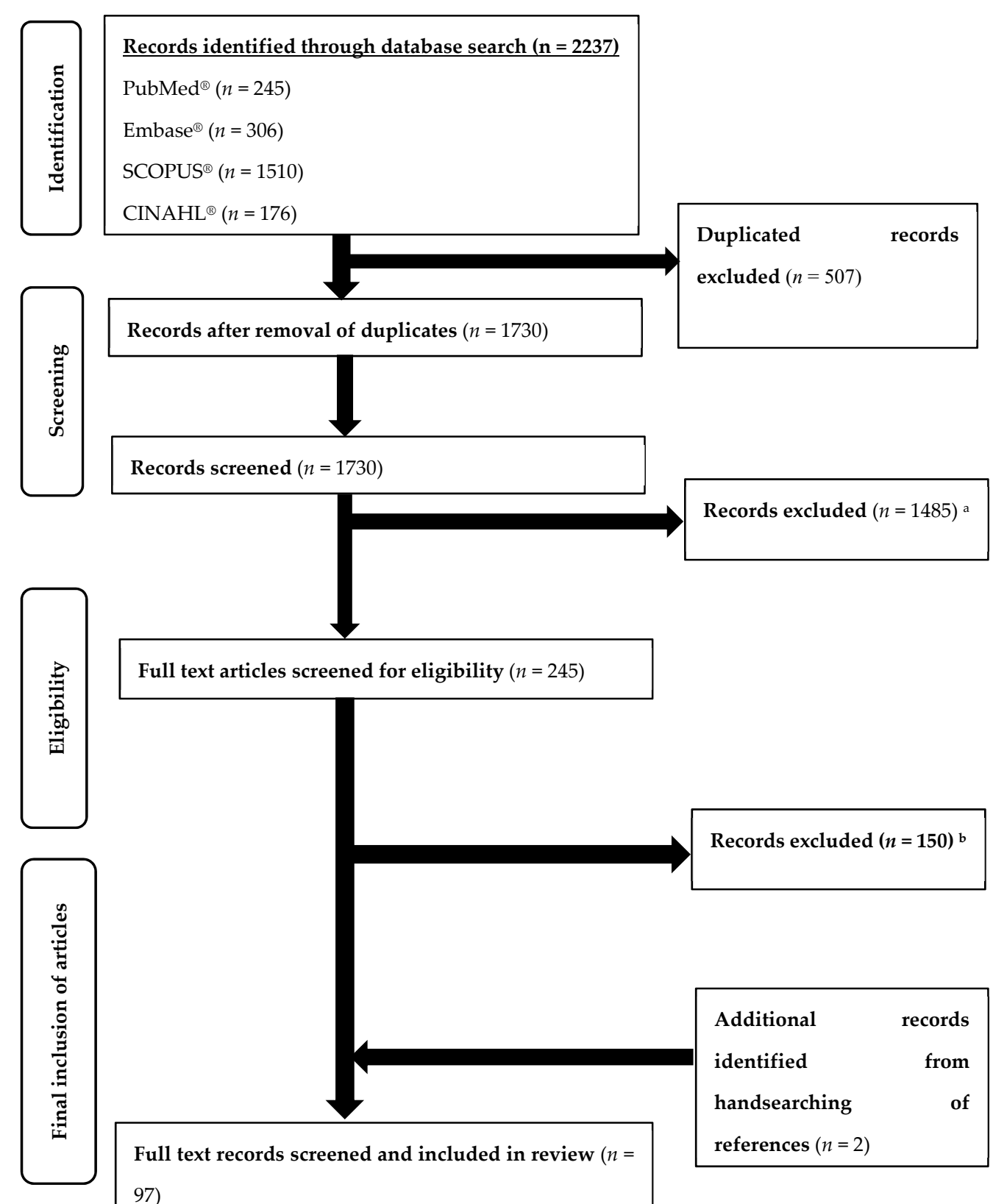

Figure 1. Flowchart for retrieval of articles. ${ }^{a}$ Records excluded: Did not evaluate COVID-19 related vaccine hesitancy $(n=1425)$; Evaluated vaccine hesitancy in non-high-income countries $(n=34)$; non-English articles $(n=23)$; irrelevant systematic reviews/meta-analyses $(n=3) ;{ }^{\mathrm{b}}$ Records excluded: Studies included countries other than high-income countries $(n=14)$; studies are editorials, commentaries, news article and/or opinions without original data $(n=132)$; Study looked at willingness of guardians enrolling children in vaccine trials $(n=1)$; studies retracted $(n=3)$.

\subsection{Characteristics of Included Studies}

In the summary table of the characteristics of included studies, approximately half of the included studies were conducted in Year 2021 (50.5\%) while the other half were performed in $2020(49.5 \%)$ (Table 1). Most of the studies were conducted in North America $(43.3 \%)$ and Europe (34.0\%). Four studies involved cross-continent collaborations. Of note, the two countries with the highest number of studies were U.S. $(n=39,40.2 \%)$ and Italy $(n=9,9.3 \%)$. Cross-sectional study design $(n=75,77.3 \%)$ and online survey methodology $(n=87,89.7 \%)$ were most frequently described in studies included. Further details of included studies are available in Supplementary File Table S2. 
Table 1. Characteristics of included studies $(n=97)$.

\begin{tabular}{|c|c|}
\hline Variables & $n(\%)$ \\
\hline \multicolumn{2}{|l|}{ Year of study } \\
\hline 2019 & $0(0)$ \\
\hline 2020 & $48(49.5)$ \\
\hline 2021 & $49(50.5)$ \\
\hline \multicolumn{2}{|l|}{ Continent of study } \\
\hline North America & $42(43.3)$ \\
\hline Europe & $33(34)$ \\
\hline Asia & $11(11.3)$ \\
\hline Oceania & $7(7.2)$ \\
\hline Cross-continents & $4(4.1)$ \\
\hline \multicolumn{2}{|l|}{ Country of study } \\
\hline USA & $39(40.2)$ \\
\hline Italy & $9(9.3)$ \\
\hline Multiple countries & $9(9.3)$ \\
\hline Australia & $6(6.2)$ \\
\hline France & $6(6.2)$ \\
\hline Hong Kong & $4(4.1)$ \\
\hline U.K. & $8(8.2)$ \\
\hline Germany & $2(2.1)$ \\
\hline Poland & $2(2.1)$ \\
\hline UAE & $2(2.1)$ \\
\hline Canada & $2(2.1)$ \\
\hline Other countries $^{a}$ & $8(8.2)$ \\
\hline \multicolumn{2}{|l|}{ Patient populations } \\
\hline General public & $71(73.2)$ \\
\hline Healthcare workers & $13(13.4)$ \\
\hline University students and/or university staff & $5(5.2)$ \\
\hline Patients with autoimmune conditions & $3(3.1)$ \\
\hline Patients with malignancy & $1(1)$ \\
\hline Adolescents and/or children & $1(1)$ \\
\hline Others ${ }^{b}$ & $3(3.1)$ \\
\hline \multicolumn{2}{|l|}{ Number of study participants } \\
\hline $0-1000$ & $28(28.9)$ \\
\hline $1001-2000$ & $32(33)$ \\
\hline $2001-5000$ & $25(25.8)$ \\
\hline $5001-10,000$ & $11(11.3)$ \\
\hline$>10,000$ & $1(1)$ \\
\hline
\end{tabular}


Table 1. Cont.

\begin{tabular}{|c|c|}
\hline Variables & $n(\%)$ \\
\hline \multicolumn{2}{|l|}{ Study design } \\
\hline Cross-sectional study & $75(77.3)$ \\
\hline Mixed methods & $14(14.4)$ \\
\hline Randomized controlled trials & $2(2.1)$ \\
\hline Pure qualitative study & $1(1)$ \\
\hline Case control study & $2(2.1)$ \\
\hline Longitudinal study & $3(3.1)$ \\
\hline \multicolumn{2}{|l|}{ Methodology of data collection ${ }^{\#}$} \\
\hline Online survey & $87(89.7)$ \\
\hline Telephone interview & $7(7.2)$ \\
\hline Paper questionnaire & $3(3.1)$ \\
\hline Face-to-face survey & $2(2.1)$ \\
\hline Focus group discussion & $2(2.1)$ \\
\hline Combinations of methods ${ }^{c}$ & $5(5.2)$ \\
\hline \multicolumn{2}{|l|}{ Response rates } \\
\hline $0-<25 \%$ & $5(5.2)$ \\
\hline $25-<50 \%$ & $7(7.2)$ \\
\hline $50-<75 \%$ & $15(15.5)$ \\
\hline $75-100 \%$ & $17(17.5)$ \\
\hline Not specified & $53(54.6)$ \\
\hline \multicolumn{2}{|l|}{ Use of validated questionnaire } \\
\hline Yes & $26(26.8)$ \\
\hline No & $71(73.2)$ \\
\hline \multicolumn{2}{|c|}{ COVID-19 vaccine hesitancy $30 \%$ or more across continents $d, e$} \\
\hline North America & $25 / 42(59.5)$ \\
\hline Europe & $11 / 33(33.3)$ \\
\hline Asia & $8 / 11(72.7)$ \\
\hline Oceania & $2 / 7(28.6)$ \\
\hline
\end{tabular}

a Finland $(n=1)$, Greece $(n=1)$, Israel $(n=1)$, Japan $(n=1)$, Kuwait $(n=1)$, New Zealand $(n=1)$, Qatar $(n=1)$, Saudi Arabia $(n=1) .{ }^{\mathrm{b}}$ Parents/caregivers $(n=1)$, firefighters / first responders $(n=1)$, Blacks living with HIV $(n=1){ }^{c}$ Studies using a combination of either of online, face to face, paper questionnaire, telephone or mail methods included. ${ }^{\mathrm{d}}$ Studies involving participants from multi-continents $(n=4)$ are omitted in the table e Studies reporting guardians' vaccine hesitancy for their wards included in the analysis (if a study reports both guardians' hesitancy for wards and for themselves, the higher of the 2 is taken into consideration for count here). \# Each category has been reported as per described in individual study and the net total will be more than 97 due to some studies having combination methods.

\subsection{Study Population}

Across the populations studied, most studies evaluated vaccine hesitancy rates among the general public $(n=71,73.2 \%)$ and healthcare workers $(n=13,13.4 \%)$. Other studied populations included university students/staff $(n=5,5.2 \%)$ and patients $(n=4,4.1 \%)$. Among the included studies, only 10 studies (10.3\%) evaluated participants' hesitancy towards COVID-19 vaccination for their children [15,18-25]. 


\subsection{Vaccine Hesitancy Rates across Studies}

Figure 2 shows a bar chart illustrating vaccine hesitancy rates and number of studies done in high income countries. Among the 97 studies included, 46 studies had vaccine hesitancy of $30 \%$ and more (Table 1). Among the four continents exploring vaccine hesitancy in high income countries, Asia had the highest proportion of studies with vaccine hesitancy of $30 \%$ or more $[n=8(72.7 \%)]$ while North America ranked second $[n=25$ $(59.5 \%)]$. Studies conducted in Europe and Oceania had a lower proportion of studies with vaccine hesitancy $30 \%$ or more. Individually, vaccine hesitancy rates were highest in UAE (77.9\%), U.S. (66.8\%), Hong Kong (60\%), and Italy (59.9\%). In contrast, the vaccine hesitancy rates were lowest in Canada (7\%) and Saudi Arabia (7\%).

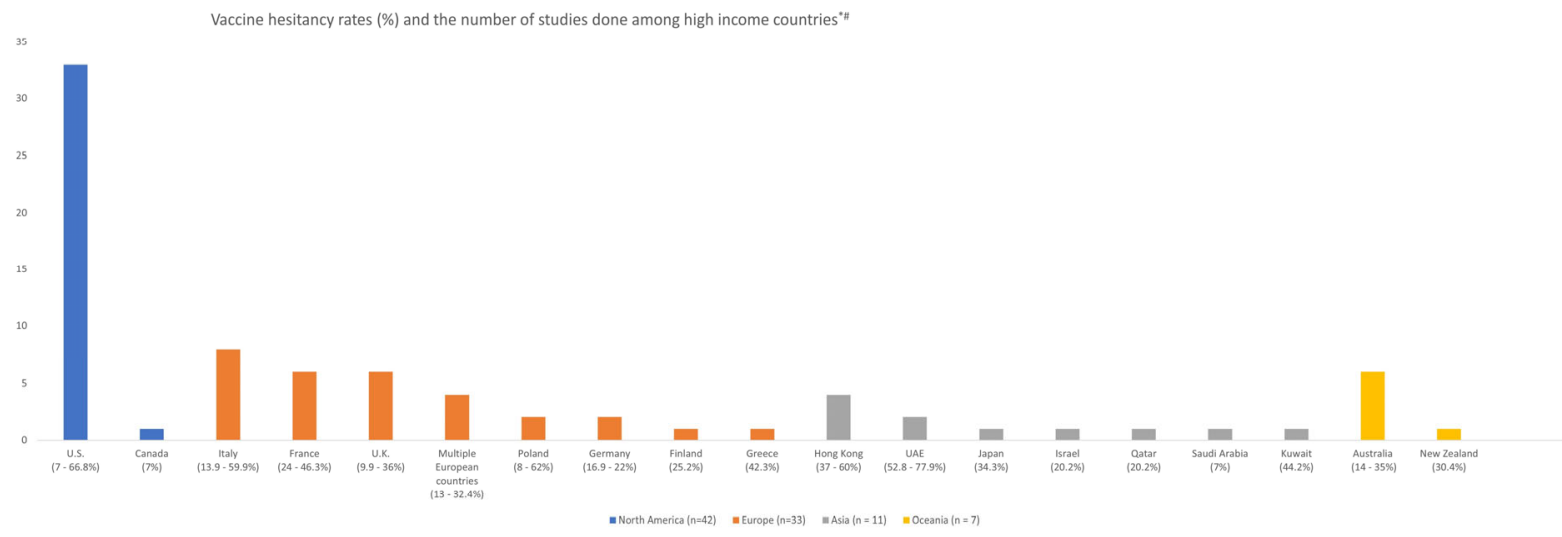

Figure 2. Studies on vaccine hesitancy and its corresponding rates among high income countries. ${ }^{*}$ Only studies with reported vaccine hesitancy rates were included in Figure 2. \# 4 studies performed in multi-continents not included to prevent double counting. Abbreviations: U.S.-United States; UAE-United Arab Emirates.

Reasons for vaccine hesitancy/acceptance were explored in 21 studies through open ended questions but only 7 (7.2\%) attempted to describe methods on thematic analysis. Of these, only four are qualitative studies with well described methodologies [23,25-27]. Cross-sectional studies $(n=75,77.3 \%)$ were the most frequent study designs while online surveys $(83,85.6 \%)$ were the most frequently used methods ${ }^{a}$.

Pertaining to the definition of vaccine hesitancy used to derive its proportion, just slightly over half of the studies (51.5\%) conformed to SAGE working group definition of vaccine hesitancy ${ }^{a} \cdot{ }^{a}$ Detailed data available in Supplementary Materials Table S2.

\subsection{Determinants of Vaccine Hesitancy}

\subsubsection{Contextual Related Factors}

A total of 25 themes were identified and grouped under the eight sub-categories in "Contextual determinants of vaccine hesitancy" (Table 2). "Sociodemographic related variables", "policies/politics related factors", and "communications and media environment related factors" were most frequently studied themes. 
Table 2. Contextual determinants of vaccine related hesitancy in high-income countries or regions.

\begin{tabular}{|c|c|c|c|c|c|c|}
\hline Factor & $\begin{array}{l}\text { Number of } \\
\text { Supporting } \\
\text { Studies }\end{array}$ & References & $\begin{array}{l}\text { Number of } \\
\text { Studies } \\
\text { Which } \\
\text { Found no } \\
\text { Significance }\end{array}$ & References & $\begin{array}{l}\text { Number of } \\
\text { Disagreeing } \\
\text { Studies }\end{array}$ & References \\
\hline \multicolumn{7}{|l|}{$\begin{array}{l}\text { Communication and } \\
\text { media environment }\end{array}$} \\
\hline $\begin{array}{l}\text { Participants whose sources } \\
\text { of information are mainly } \\
\text { via social media/internet }\end{array}$ & 6 & [28-33] & 1 & {$[34]$} & 0 & \\
\hline $\begin{array}{l}\text { Lack of widely accessible } \\
\text { information on vaccine } \\
\text { related information }\end{array}$ & 5 & {$[29,35-38]$} & 1 & [39] & 0 & \\
\hline $\begin{array}{l}\text { Participants who are mainly } \\
\text { users of non-traditional } \\
\text { media (not radio, not } \\
\text { newspapers, not television) }\end{array}$ & 3 & {$[30,32,34]$} & 1 & [33] & 0 & \\
\hline \multicolumn{7}{|l|}{$\begin{array}{l}\text { Influential leaders, } \\
\text { gatekeepers and anti or } \\
\text { pro-vaccination lobbies }\end{array}$} \\
\hline $\begin{array}{l}\text { Preferences for Donald } \\
\text { Trump endorsements of } \\
\text { vaccination }\end{array}$ & 2 & {$[40,41]$} & 1 & {$[42]$} & 0 & \\
\hline $\begin{array}{l}\text { Preferences for Dr. Anthony } \\
\text { Fauci pro-vaccination } \\
\text { endorsements }\end{array}$ & 0 & & 0 & & 2 & {$[41,42]$} \\
\hline \multicolumn{7}{|l|}{ Policies/politics } \\
\hline $\begin{array}{l}\text { Political inclination: U.S. } \\
\text { Democrats supporters }\end{array}$ & 0 & & 0 & & 8 & {$[33,40,41,43-47]$} \\
\hline $\begin{array}{l}\text { Political inclination: Non } \\
\text { liberals (Far right, far left, } \\
\text { conservative) }\end{array}$ & 8 & {$[40,46,48-53]$} & 2 & {$[22,54]$} & 0 & \\
\hline Mandatory vaccination & 2 & {$[55,56]$} & 0 & & 0 & \\
\hline $\begin{array}{l}\text { Political inclination: Vote } \\
\text { abstinence }\end{array}$ & 1 & [48] & 0 & & 0 & \\
\hline \multicolumn{7}{|l|}{ Religion } \\
\hline Increased religiosity & 5 & {$[31,37,40,56,57]$} & 2 & {$[41,43]$} & 1 & {$[30]$} \\
\hline \multicolumn{7}{|l|}{ Sociodemographic related } \\
\hline Females & 37 & $\begin{array}{c}{[15,20,24,33,35-} \\
37,40,41,44,46,48,50- \\
54,56-75]\end{array}$ & 12 & {$[22,34,38,43,76-83]$} & 1 & {$[84]$} \\
\hline Younger participants & 31 & $\begin{array}{c}{[32,35-37,41,46,49,53,} \\
54,56,60,63,65-68,70- \\
73,76,78,79,83-89]\end{array}$ & 12 & $\begin{array}{c}{[15,34,50,52,58,61,} \\
74,77,81,90-92]\end{array}$ & 10 & $\begin{array}{l}{[20,30,31,43,48,} \\
57,59,75,93,94]\end{array}$ \\
\hline Non-whites & 24 & $\begin{array}{c}{[23,31,32,37,40,41,45,} \\
47,49,51,52,54,64,65,68, \\
70-72,78,86,87,89,93]\end{array}$ & 6 & {$[22,33,50,79,84,90]$} & 1 & [43] \\
\hline $\begin{array}{l}\text { Lower education (below } \\
\text { college) }\end{array}$ & 19 & $\begin{array}{c}{[32,34,36,41,49,54,65} \\
66,68,69,71,77,82,85,86 \\
89,95-97]\end{array}$ & 14 & $\begin{array}{c}{[20,30,33,38,43,53,} \\
56,58,76,78,79,90 \\
92,98]\end{array}$ & 0 & \\
\hline Lower income & 13 & $\begin{array}{c}{[23,30,40,44,48,49,51-} \\
54,82,89,97]\end{array}$ & 12 & $\begin{array}{l}22,33,50,56,58,68, \\
77,80,81,86,90,92]\end{array}$ & 0 & \\
\hline $\begin{array}{c}\text { HCW without clinical roles } \\
\text { (ref: HCW with clinical } \\
\text { roles) }\end{array}$ & 7 & {$[15,61,64,65,70,73,87]$} & 0 & & 2 & {$[67,72]$} \\
\hline $\begin{array}{l}\text { Students in HC discipline } \\
\text { (ref: students in non-HC } \\
\text { disciplines) }\end{array}$ & 0 & & 1 & [99] & 0 & \\
\hline
\end{tabular}


Table 2. Cont.

\begin{tabular}{|c|c|c|c|c|c|c|}
\hline Factor & $\begin{array}{l}\text { Number of } \\
\text { Supporting } \\
\text { studies }\end{array}$ & References & $\begin{array}{l}\text { Number of } \\
\text { Studies } \\
\text { Which } \\
\text { Found no } \\
\text { Significance }\end{array}$ & References & $\begin{array}{l}\text { Number of } \\
\text { Disagreeing } \\
\text { Studies }\end{array}$ & References \\
\hline Non-Asians & 4 & {$[66,70,71,89]$} & 3 & {$[65,79,90]$} & 1 & [87] \\
\hline Presence of child at home & 3 & {$[15,44,54]$} & 4 & {$[30,58,84,98]$} & 0 & \\
\hline Married & 2 & {$[54,78]$} & 5 & {$[33,38,51,92,98]$} & 3 & {$[20,75,76]$} \\
\hline \multicolumn{7}{|l|}{$\begin{array}{c}\text { Geographical barriers (i.e., } \\
\text { accessibility) }\end{array}$} \\
\hline $\begin{array}{l}\text { Rural regions (residence, } \\
\text { place of practice) }\end{array}$ & 5 & {$[46,65,68,86,100]$} & 3 & {$[38,51,101]$} & 1 & [57] \\
\hline \multicolumn{7}{|l|}{$\begin{array}{c}\text { Pharmaceutical/governmenta } \\
\text { motives }\end{array}$} \\
\hline $\begin{array}{l}\text { Lower trust in } \\
\text { pharmaceutical industry }\end{array}$ & 4 & {$[37,41,92,102]$} & 0 & & 0 & \\
\hline Lower trust in government & 3 & {$[20,56,79]$} & 0 & & 0 & \\
\hline \multicolumn{7}{|l|}{ Others } \\
\hline $\begin{array}{l}\text { Increased passage of time } \\
\text { longitudinally in pandemic }\end{array}$ & 5 & {$[34,68,71,75,94]$} & 2 & {$[56,82]$} & 0 & \\
\hline $\begin{array}{l}\text { Participants without } \\
\text { healthcare insurance }\end{array}$ & 3 & {$[52,68,84]$} & 0 & & 0 & \\
\hline
\end{tabular}

Abbreviation: HC-healthcare.

Among the sociodemographic variables, being females $(n=37),[15,20,24,33,35-37,40$, $41,44,46,48,50-54,56-75]$ having a younger age $(n=31)[32,35-37,41,46,49,53,54,56,60,63,65-$ 68,70-73,76,78,79,83-89] being of non-White ethnicity $(n=24),[23,31,32,37,40,41,45,47,49$, $51,52,54,64,65,68,70-72,78,86,87,89,93]$ having a lower education $(n=19)[32,34,36,41,49,54$, $65,66,68,69,71,77,82,85,86,89,95-97]$ and a lower income level $(n=13)[23,30,40,44,48,49,51-$ $54,82,89,97]$ were associated with vaccine hesitancy.

With regards to policies and politics related factors, political inclination towards nondemocrats in the U.S. $(n=8)[33,40,41,43-47]$ and non-liberals $(n=8)[40,46,48-53]$ were associated with vaccine hesitancy.

For communications and media environment factors, the use of social media or internet as a main source of information $(n=6)$ [28-33] and the lack of widely accessible information on COVID-19 vaccination $(n=5)$ [29,35-38] were associated with vaccine hesitancy.

Other notable factors associated with vaccine hesitancy included healthcare workers in non-clinical roles (compared to those in clinical roles) $(n=7)$, [15,61,64,65,70,73,87] increased religiosity $(n=5),[31,37,40,56,57]$ residing in rural areas $(n=5),[46,65,68,86,100]$ reduced trust in government and pharmaceutical industry $(n=7)[20,37,41,56,79,92,102]$ and increased passage of time in a pandemic $(n=5)[34,68,71,75,94]$.

Two studies found an increased vaccine hesitancy mainly in nursing staff among healthcare workers with clinical fronting roles $[67,72]$.

\subsubsection{Group/Individual Related Factors}

A total of seven sub-categories of factors with 22 themes were identified for the "Individual/group determinants of vaccine hesitancy" (Table 3). "Beliefs, attitudes about health and prevention", "past experiences with vaccinations", and "health-system and providers-trust and personal experience" were most well-studied. 
Table 3. Individual/group determinants of increased vaccine hesitancy in high-income countries or regions.

\begin{tabular}{|c|c|c|c|c|c|c|}
\hline Factor & $\begin{array}{l}\text { Number of } \\
\text { Supporting } \\
\text { Studies }\end{array}$ & References & $\begin{array}{l}\text { Number of } \\
\text { Studies Which } \\
\text { Found no } \\
\text { Significance } \\
\end{array}$ & References & $\begin{array}{l}\text { Number of } \\
\text { Disagreeing } \\
\text { Studies }\end{array}$ & References \\
\hline \multicolumn{7}{|l|}{ Experience with past vaccination } \\
\hline History of influenza vaccination & 0 & & 1 & [103] & 28 & $\begin{array}{c}{[15,19,20,22,25,33,35-} \\
37,41,46,47,49,50,58 \\
61,65,66,68,73-75,78, \\
79,86,89,90,95,104]\end{array}$ \\
\hline $\begin{array}{l}\text { Having children with up-to-date } \\
\text { vaccinations }\end{array}$ & 0 & & 0 & & 1 & [25] \\
\hline \multicolumn{7}{|l|}{$\begin{array}{l}\text { Beliefs, attitudes about health } \\
\text { and prevention }\end{array}$} \\
\hline $\begin{array}{l}\text { Lesser fear for health or worry } \\
\text { about COVID-19 }\end{array}$ & 16 & $\begin{array}{c}{[32,33,35,37,38,40,49,53,54} \\
59,61,67,68,79,81,90]\end{array}$ & 2 & {$[80,103]$} & 2 & {$[28,37]$} \\
\hline $\begin{array}{l}\text { Perception of lower risk of } \\
\text { contracting COVID-19 }\end{array}$ & 15 & $\begin{array}{c}{[28,43,44,49,52,54,59,61,63} \\
81,94,96,98,104,105]\end{array}$ & 4 & {$[51,55,74,92]$} & 1 & {$[69]$} \\
\hline Belief that COVID-19 is not severe & 12 & $\begin{array}{c}{[22,36,41,49,52,58,63,64,81} \\
92,98,105]\end{array}$ & 1 & {$[43]$} & 1 & [69] \\
\hline Greater conspiracy beliefs & 8 & {$[30,32,50,54,98,106-108]$} & 1 & {$[80]$} & 0 & \\
\hline $\begin{array}{c}\text { Belief in greater efficacy of } \\
\text { complementary alternative } \\
\text { medicine or one's natural immune } \\
\text { system }\end{array}$ & 5 & {$[20,29,62,73,102]$} & 0 & & 0 & \\
\hline $\begin{array}{l}\text { Belief that COVID-19 is not a } \\
\text { disease }\end{array}$ & 4 & {$[20,58,85,109]$} & 0 & & 0 & \\
\hline $\begin{array}{l}\text { Belief that threat of COVID-19 is } \\
\text { exaggerated }\end{array}$ & 2 & {$[85,109]$} & 0 & & 0 & \\
\hline $\begin{array}{l}\text { Lesser compliance with } \\
\text { COVID-19 prevention behaviors }\end{array}$ & 2 & {$[22,51]$} & 0 & & 0 & \\
\hline \multicolumn{7}{|l|}{ Knowledge and awareness } \\
\hline $\begin{array}{l}\text { Lower knowledge about } \\
\text { COVID-19 }\end{array}$ & 4 & {$[38,79,85,98]$} & 3 & {$[22,37,52]$} & 0 & \\
\hline $\begin{array}{l}\text { Lower knowledge about } \\
\text { vaccination }\end{array}$ & 1 & [33] & 2 & {$[22,37]$} & 0 & \\
\hline \multicolumn{7}{|l|}{$\begin{array}{l}\text { Health-system and } \\
\text { providers-trust and personal } \\
\text { experience }\end{array}$} \\
\hline Lesser trust in healthcare system & 11 & $\begin{array}{c}{[22,30,32,50,62,68,73,92,} \\
106-108]\end{array}$ & 2 & {$[80,81]$} & 0 & \\
\hline $\begin{array}{l}\text { Lesser trust in science or in } \\
\text { scientist }\end{array}$ & 9 & {$[30,33,35,40,54,55,58,73,91]$} & 0 & & 0 & \\
\hline \multicolumn{7}{|l|}{$\begin{array}{c}\text { Immunization as a social norm } \\
\text { vs. not needed/harmful }\end{array}$} \\
\hline $\begin{array}{c}\text { Belief that vaccination is } \\
\text { non-beneficial and/or } \\
\text { unimportant }\end{array}$ & 12 & $\begin{array}{c}{[20,31,37,43,54,68,78,90-} \\
92,102,105]\end{array}$ & 0 & & 0 & \\
\hline $\begin{array}{l}\text { Belief that vaccination is a } \\
\text { hoax/harmful }\end{array}$ & 1 & $(32,92)$ & 1 & [20] & 0 & \\
\hline \multicolumn{7}{|l|}{ Humanistic traits } \\
\hline $\begin{array}{l}\text { Lesser sense of collective } \\
\text { responsibility e.g., protect loved } \\
\text { ones, neighbors }\end{array}$ & 10 & $\begin{array}{c}{[30,35,37,49,54,89,90,94} \\
101,109]\end{array}$ & 2 & {$[55,103]$} & 0 & \\
\hline Lower self-efficacy & 4 & {$[31,43,54,105]$} & 0 & & 0 & \\
\hline \multicolumn{7}{|l|}{ Other factors } \\
\hline $\begin{array}{l}\text { No concomitant chronic diseases } \\
\text { or not taking regular medications }\end{array}$ & 11 & $\begin{array}{c}{[20,30,33,36,57,62,74,78,82} \\
89,98]\end{array}$ & 8 & $\begin{array}{l}{[25,33,46,61,75} \\
\quad 84,90,92]\end{array}$ & 2 & {$[64,69]$} \\
\hline $\begin{array}{l}\text { Peers or family with previous } \\
\text { COVID-19 infection }\end{array}$ & 0 & & 4 & {$[22,30,46,103]$} & 3 & {$[33,67,89]$} \\
\hline $\begin{array}{l}\text { Greater desire to return to } \\
\text { normalcy }\end{array}$ & 0 & & 0 & & 2 & {$[35,37]$} \\
\hline $\begin{array}{l}\text { Previously tested for COVID-19 } \\
\text { antibodies or do not mind testing } \\
\text { for COVID-19 antibodies }\end{array}$ & 0 & & 0 & & 3 & {$[40,54,65]$} \\
\hline
\end{tabular}

A lesser fear for health or worry about COVID-19 $(n=16),[32,33,35,37,38,40,49,53,54$, $59,61,67,68,79,81,90]$ a perception of lower risk of contracting COVID-19 $(n=15),[28,43,44$, 
$49,52,54,59,61,63,81,94,96,98,104,105]$ believing that COVID-19 is not severe ( $n=12)$, [22, $36,41,49,52,58,63,64,81,92,98,105]$ having lesser trust in healthcare system $(n=11)[22,30$, $32,50,62,68,73,92,106-108]$ and believing that vaccination is unimportant or non-beneficial $(n=12)[20,31,37,43,54,68,78,90-92,102,105]$ were most frequently studied associations with increased vaccine hesitancy.

Previous influenza vaccination was the most common determinant associated with lower vaccine hesitancy $(n=28)[15,19,20,22,25,33,35-37,41,46,47,49,50,58,61,65,66,68,73-$ $75,78,79,86,89,90,95,104]$.

\subsubsection{Vaccine Related Factors}

A total of 10 themes were identified and grouped under the original eight subcategories for "Vaccine related determinants" of vaccine hesitancy (Table 4). Among these, factors related to "risk and benefits of the vaccine" and "introduction of new vaccine/formulation" were the most studied subcategories.

Table 4. Vaccine related determinants of vaccine hesitancy in high-income countries or regions.

\begin{tabular}{|c|c|c|c|c|c|c|}
\hline Factor & $\begin{array}{l}\text { Number of } \\
\text { Supporting } \\
\text { Studies }\end{array}$ & References & $\begin{array}{l}\text { Number of } \\
\text { Studies Which } \\
\text { Found no } \\
\text { Significance } \\
\end{array}$ & References & $\begin{array}{l}\text { Number of } \\
\text { Disagreeing } \\
\text { Studies }\end{array}$ & References \\
\hline \multicolumn{7}{|l|}{ Risk/benefit (scientific evidence) } \\
\hline $\begin{array}{c}\text { Belief that the COVID-19 vaccines are } \\
\text { unsafe or ineffective }\end{array}$ & 24 & $\begin{array}{c}{[20,22,29,35-} \\
37,40,41,43,50,52 \\
54,55,63,68,73,88 \\
90,94,102,103,108 \\
110,111]\end{array}$ & 1 & [69] & 0 & \\
\hline $\begin{array}{l}\text { Perceived duration of protection from } \\
\text { COVID-19 vaccines to be short (one } \\
\text { year or less) }\end{array}$ & 1 & [73] & 0 & & 0 & \\
\hline \multicolumn{7}{|l|}{$\begin{array}{l}\text { Introduction of new } \\
\text { vaccine/formulation }\end{array}$} \\
\hline $\begin{array}{l}\text { Concerns about rapid development, } \\
\text { novelty, and / or mechanism of action } \\
\text { of vaccine }\end{array}$ & 9 & $\begin{array}{c}{[20,22,24,41,43,50} \\
54,108,110]\end{array}$ & 1 & [22] & 0 & \\
\hline \multicolumn{7}{|l|}{ Mode of administration } \\
\hline $\begin{array}{l}\text { Fear of needles as a route of vaccine } \\
\text { administration }\end{array}$ & 2 & {$[37,111]$} & 0 & & 0 & \\
\hline \multicolumn{7}{|l|}{$\begin{array}{l}\text { Reliability or source of vaccine } \\
\text { supply }\end{array}$} \\
\hline $\begin{array}{l}\text { Vaccines developed by first world } \\
\text { regions (US and European Union) }\end{array}$ & 0 & & 0 & & 3 & {$[22,36,110]$} \\
\hline \multicolumn{7}{|l|}{ Vaccination schedule } \\
\hline $\begin{array}{l}\text { Concerns about vaccine requiring } \\
\text { more than one dose }\end{array}$ & 2 & {$[88,110]$} & 0 & & 0 & \\
\hline \multicolumn{7}{|l|}{$\begin{array}{l}\text { Design of vaccination program/mode } \\
\text { of delivery }\end{array}$} \\
\hline $\begin{array}{l}\text { Presence of perceived barriers to } \\
\text { accessibility of vaccine (i.e., location } \\
\text { for vaccination, time spent on } \\
\text { transport) }\end{array}$ & 4 & {$[36,92,97,111]$} & 0 & & 0 & \\
\hline \multicolumn{7}{|l|}{ Role of Healthcare professional } \\
\hline $\begin{array}{l}\text { Lack of advocacy for COVID-19 } \\
\text { vaccination from attending physician }\end{array}$ & 3 & {$[49,52,88]$} & 1 & {$[34]$} & 0 & \\
\hline \multicolumn{7}{|l|}{ Costs } \\
\hline $\begin{array}{l}\text { Concerns for costs of COVID-19 } \\
\text { vaccination }\end{array}$ & 2 & {$[97,104]$} & 2 & {$[43,90]$} & 0 & \\
\hline $\begin{array}{l}\text { Availability of monetary incentives to } \\
\text { get vaccinated }\end{array}$ & 0 & & 1 & [39] & 0 & \\
\hline
\end{tabular}


The most studied determinants associated with increased vaccine hesitancy included beliefs that COVID-19 vaccines are unsafe or ineffective $(n=24)[20,22,29,35-37,40,41,43$, $50,52,54,55,63,68,73,88,90,94,102,103,108,110,111]$ and concerns related to the rapid development of vaccine and/or its mechanism of action $(n=9)[20,22,24,41,43,50,54,108,110]$.

Other notable factors associated with increased vaccine hesitancy included presence of perceived barriers to accessibility of vaccine $(n=4),[36,92,97,111]$ lack of advocacy for vaccination by attending physicians $(n=3)[49,52,88]$ and multidose nature for vaccination schedule $(n=2)[88,110]$. Evidence linking concerns about cost for vaccination $(n=4)$ were mixed $[43,90,97,104]$.

\section{Discussion}

This review has highlighted a few salient points and some research gaps.

Firstly, it showed that despite the variable rates of vaccine hesitancy across highincome countries or regions, nearly half of studies reported vaccine hesitancy of $30 \%$ or more. Our review discovered that only slightly more than half of the studies conducted on COVID-19 vaccine hesitancy conformed to the SAGE proposed definition. In those studies which did not conform, participants who expressed being "unsure" instead of rejecting the vaccine were excluded in the hesitancy rate, leading to a potential falsely reassuring low hesitancy rate.

Studies conducted among high income regions across four continents revealed a high proportion of studies with high vaccine hesitancy mostly in Asia and North America. Countries with the highest vaccine hesitancy rates included UAE, U.S., Hong Kong, and Italy. Compared to low-income countries or regions, the current vaccine hesitancy rates in high income countries or regions are worrisome.

The varying vaccine hesitancy rates across countries or regions are complex and may partly be attributed to differences in ideological beliefs, demographics, and context specific factors, as seen for other vaccinations. For example, vaccine hesitancy appears to have a lesser impact on general vaccine uptake rates in lower-middle income countries or regions and affects lower socioeconomic status individuals to a greater extent [112]. The reasons have been linked to disparities in access, cost, and awareness of vaccines [113]. In contrast, individuals residing in more affluent countries or regions tend to be more vaccine hesitant due to concerns related to the safety of vaccines [114]. This is especially so in the current choices of vaccines made with newer technology which raised doubts and long term safety concerns [115].

The global vaccination census showed that the share of population fully vaccinated against COVID-19 stood at 18.3\% in high income countries or regions as of May 2021 [116]. Of note, the proportions of population fully vaccinated against COVID-19 in U.S., Italy, Hong Kong, and UAE were at 36\%, 13.7\%, 10\%, and 38.8\% as of May 2021 respectively, reflecting our review results with only UAE bucking the trend [116]. In spite of this, there were flattening of the epidemic curves from February onwards in the U.S. and Israel after the commencement of vaccination exercises, reinforcing the importance of vaccination [1].

The second point our study highlighted was to summarize determinants of COVID-19 vaccine hesitancy that were the frequently studied (Figure 3). Females, being younger, having a non-Whites ethnicity and having a lower socioeconomic status (e.g., lower education or income levels) were common demographics identified with COVID-19 vaccine hesitancy (Table 2).

Literature discussing higher vaccine hesitancy in females suggested the underlying reasons attributable to lower perceived risk of COVID-19, higher beliefs in conspiracy related theories about the pandemic compared to their male counterparts [117] and concerns about safety of vaccination in pregnancy and breastfeeding [118].

The association between younger individuals and COVID-19 vaccine hesitancy may be a result of increased public health focus on vaccinating the elderly (due to their risk for severe COVID-19 outcomes) and the lack of outreach on COVID-19 vaccination in social media platforms which they commonly frequent [119]. 


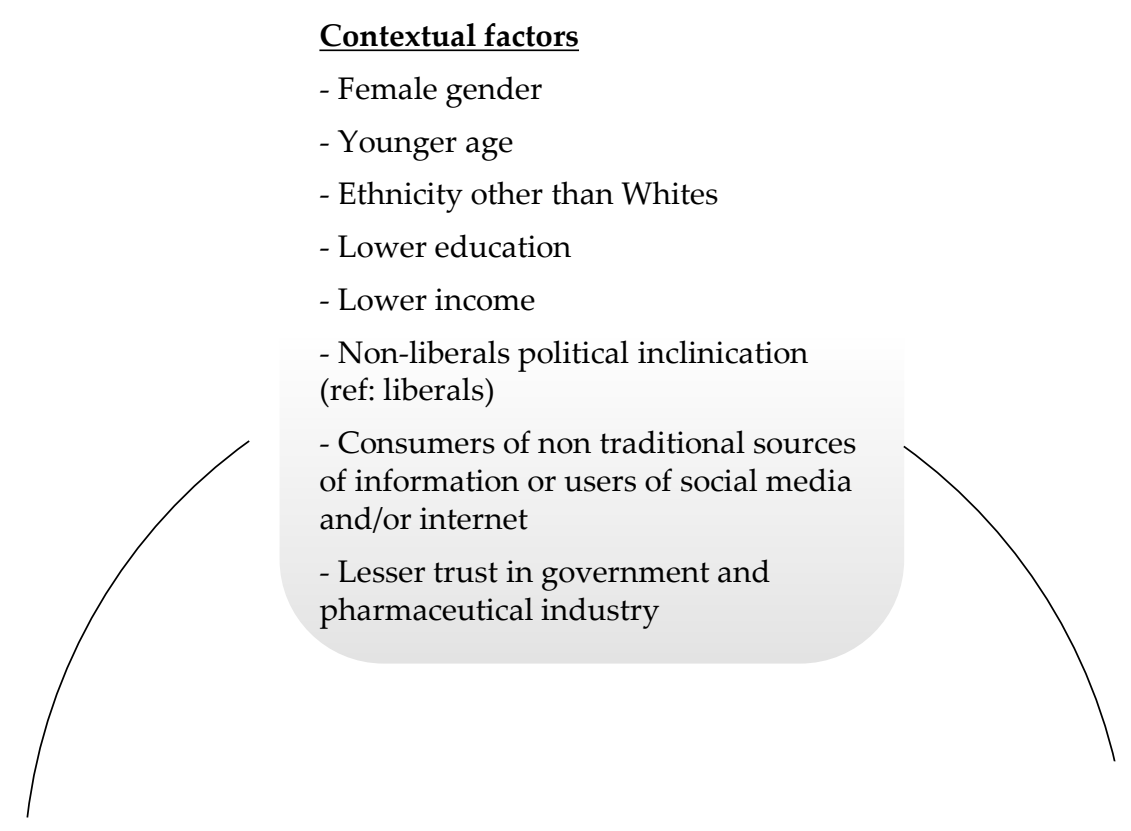

\section{Vaccine related determinants}

- Belief that vaccines are not safe or efficacious

- Concerns about rapid development of vaccine and/or its mechanism of action

- Increased perceived barriers on accessibility to vaccine

- Lack of advocacy for vaccination by physicians

- Development of vaccine in non-first world country

\section{Group / Individual factors}

- Lesser fear for health

- Low risk perception of contracting COVID-19

- Nil previous influenza vaccination

- Strong beliefs that COVID-19 is not severe

- Less trust in science and healthcare system

Figure 3. Framework diagram summarizing key determinants of vaccine hesitancy in high-income countries or regions.

With respect to ethnicity, Blacks have been shown to have increased mistrust in COVID19 vaccination with possible reasons due to racism, discrimination and mistreatment within the healthcare systems [120]. We should extrapolate and observe for similar associations to all at-risk populations so that governments and healthcare professionals alike can assess and direct efforts on improving COVID-19 vaccination uptake rates.

Our review also discovered that users of social media/internet as a primary source of COVID-19 related information were more prone to increased vaccine hesitancy. With the advent of infodemic on these non-traditional media platforms, innovations on ways to deliver accurate and timely health information by traditional and non-traditional platforms have become incredibly important. Employing active strategies such as pre-emptive cognitive inoculation techniques and pre-bunking techniques have also been suggested to tackle misinformation [121]. Clear and honest communications form an important bridge between building public trust and reinforcing positive health behaviors or compliance with COVID-19 vaccination [122].

In addition, the other determinants previously mentioned should also be systematically addressed. While it is not within the scope of this review, the way different themes are being measured such as knowledge about COVID-19 disease and vaccination, is an important area of research impacting on the study of vaccine hesitancy across different populations. Our review noted that most studies used self-designed instruments in the 
evaluation of COVID-19 vaccination knowledge which limits cross-comparison of knowledge levels across populations. Future research should consider developing a standardized instrument for the assessment of knowledge of COVID-19 vaccine and disease which can potentially be adapted for future pandemics.

Hopefully, the summary of these determinants will allow policymakers at the national level to deep dive into local context and conduct multi-pronged, multi-tiered studies coupled with interventions to overcome vaccine hesitancy in high income countries.

With the ongoing vaccination drive globally and evolving landscape for COVID-19, it remains premature to conclude the real-world impact of vaccine hesitancy on the true uptake of COVID-19 vaccination. Uptake can be confounded by logistic and administrative challenges in vaccine deployment, vaccine production capacity issues from manufacturers, affordability of vaccines and global allocation of vaccines in the context of limited supplies [123]. This was observed in U.A.E. which had one of the highest percentages of population fully vaccinated for COVID-19 (39.3\%) globally in May 2021 despite a reported high vaccine hesitancy [124]. In contrast, the percentage of fully vaccinated population in Canada, which had the lowest vaccine hesitancy, was only 3.3\% in May 2021 [124].

Nonetheless, vaccine hesitancy studies will continue to provide insights into possible future directions to drive vaccination efforts. In planning vaccination programs, two considerations related to COVID-19 vaccination are important moving forward. Firstly, if COVID-19 vaccinations can stop transmissibility of COVID-19, at least $60-70 \%$ of population needs to be vaccinated [125]. Secondly, in the scenario where COVID-19 vaccines reduce only disease severity but not transmissibility, identifying targeted groups for priority vaccination will become the de facto strategy. Studying vaccine hesitancy across patient subgroups who have the highest mortality and morbidity related to COVID-19 infection will be of paramount importance.

Several research gaps related to COVID-19 related vaccine hesitancy were identified in this review. Currently, there are limited studies which have evaluated longitudinal changes in COVID-19 related vaccine hesitancy. COVID-19 vaccine hesitancy may fluctuate or even increase due to fatigue with lockdown and preventive measures, or secondary to increased complacency coupled with reduced risk perceptions with a long duration of pandemic [126]. Future studies may want to consider evaluating the variation in vaccine hesitancy at different timepoints in the COVID-19 pandemic, given its continued waves of outbreaks in different countries or regions currently. There is also paucity of data related to COVID-19 vaccine hesitancy among pediatric groups as well as a lack of assessment of parental concerns of COVID-19 vaccinations in children. As data from studies evaluating the safety and efficacy of COVID-19 vaccination among children emerges soon, it is an important research area to explore. In addition, this review had noted a dismal number of qualitative studies on COVID-19 vaccine hesitancy. Qualitative studies often enable new themes to be identified which is important for comprehensiveness [127]. Albeit challenges abound in conducting qualitative research due to current climate of social distancing measures and lockdowns, some recommended ways to overcome them include use of digital text communications, video diaries and photovoice, where physical interaction can be minimized [128].

This review is not without its limitations. Firstly, the determinants of vaccine hesitancy listed in this review were factors identified from most studies which employed online surveys predominantly. While this was inevitable given the lockdowns and travel restrictions imposed during the COVID-19 pandemic, population groups with limited access to the internet such as older adults, may not be comprehensively captured.

The findings from online studies may be influenced by self-selection bias, survey fraud, and inability of respondents to seek clarity on questions [129]. Among the included studies only a small proportion of online survey studies reported their findings according to the CHERRIES checklist of internet E-surveys [130]. Future studies should consider adopting this checklist to enhance the scientific rigor of their findings. Moreover, among the included studies, we had noticed a significant number of studies not reporting the 
education level of participants recruited $(n=38 ; 39.2 \%$, data available in Supplementary Table S2). A higher level of education in the participants is associated with the possession of correct information on COVID-19 and less susceptibility to misinformation [131].

Secondly, the grey literature as well as literature from pre-print servers were not searched in this review. Future systematic reviews which seek to evaluate vaccine hesitancy among specific populations or perform an updated review should consider searching these resources to improve the comprehensiveness of the search.

Thirdly, among the 57 themes of vaccine hesitancy found in the systematic review, 26 $(45.6 \%)$ themes had fewer than five studies. The percentages in Tables $2-4$ with themes having fewer than five studies were $n=9(36 \%), 40.9 \% n=9(40.9 \%)$, and $n=8(80 \%)$ respectively. A possible insufficient exploration of a theme in the included studies has to be taken into consideration while interpreting and contextualizing the results to individual country.

We would also like to point out a preponderance of studies done in the U.S. exploring the two sub-categories on "policies/politics" and "influential leaders, gate-keepers and anti or pro-vaccination lobbies". Due to geopolitical differences, generalizability of these themes may be limited.

Lastly, assessments of methodological quality of the included studies, presentations of strength of statistical associations with vaccine hesitancy and meta-analyses of the vaccine hesitancy rates were not performed as these were not the primary aims of this scoping review. Moreover, the heterogeneity in the definition and assessment of vaccine hesitancy in different studies would not have allowed a meaningful meta-analysis. Researchers who are planning to investigate COVID-19 vaccine hesitancy may want to consider adopting the standardized definition of vaccine hesitancy from SAGE workgroup in future studies. This will facilitate and enable future systematic reviews and meta-analyses to evaluate the variation in vaccine hesitancy rates across countries or regions, as well as the temporal variation in vaccine related hesitancy.

\section{Conclusions}

Overall, COVID-19 vaccine hesitancy remains a highly prevalent problem in high income countries or regions. Individuals who were younger, females, non-Whites, and have a lower education or income levels, were more prone to vaccine hesitancy. Trust at different systems levels seem to play an important role in modifying vaccine hesitancy as well. Other commonly studied factors associated with vaccine hesitancy included a history of not receiving influenza vaccination, a lower self-perceived risk of contracting COVID-19, a lesser fear for health outcomes or COVID-19, not believing in the severity of COVID-19, having concerns about the rapid development of COVID-19 vaccines as well as disbeliefs in the safety and effectiveness of the vaccines. Healthcare administrators need to be cognizant of these determinants of vaccine hesitancy when formulating policies related to COVID-19 vaccination and public health messages.

Supplementary Materials: The following are available online at https:/ /www.mdpi.com/article/ 10.3390/vaccines9080900/s1, Table S1: Detailed search strategy, Table S2: Characteristics of included studies.

Author Contributions: Conceptualization, J.A., S.S.Y.S. and L.L.L.; methodology, J.A., J.J.B.S., S.S.Y.S. and L.L.L.; software, J.A. and J.J.B.S.; formal analysis, J.A., J.J.B.S. and S.S.Y.S.; resources, J.A. and J.J.B.S.; data curation, J.A. and J.J.B.S.; writing —original draft preparation, J.A. and J.J.B.S.; writingreview and editing, J.A. and J.J.B.S.; visualization, J.A. and J.J.B.S.; supervision, L.L.L.; funding acquisition, Not Applicable. All authors have read and agreed to the published version of the manuscript.

Funding: This research received no external funding.

Acknowledgments: The authors would like to thank the Editor and reviewers for their time and efforts spent in the review of this paper.

Conflicts of Interest: The authors declare no conflict of interest. 


\section{References}

1. World Health Organization. WHO Coronavirus Disease (COVID-19) Dashboard. Available online: https://covid19.who.int/ (accessed on 24 June 2021).

2. Hiscott, J.; Alexandridi, M.; Muscolini, M.; Tassone, E.; Palermo, E.; Soultsioti, M.; Zevini, A. The global impact of the coronavirus pandemic. Cytokine Growth Factor Rev. 2020, 53, 1-9. [CrossRef] [PubMed]

3. World Tourism Organization. UNWTO World Tourism Barometer, May 2020—Special Focus on the Impact of COVID-19 (Summary). 2020. Available online: https:/ / www.e-unwto.org/doi/book/10.18111/9789284421817 (accessed on 21 March 2021).

4. International Labor Organization. Almost 25 Million Jobs Could Be Lost Worldwide as a Result of COVID-19, Says ILO. Available online: https://www.ilo.org/global/about-the-ilo/newsroom/news/WCMS_738742/lang--en/index.htm (accessed on 21 March 2021).

5. Schoch-Spana, M.; Brunson, E.K.; Long, R.; Ruth, A.; Ravi, S.J.; Trotochaud, M.; Borio, L.; Brewer, J.; Buccina, J.; Connell, N.; et al. The public's role in COVID-19 vaccination: Human-centered recommendations to enhance pan-demic vaccine awareness, access, and acceptance in the United States. Vaccine 2020. [CrossRef] [PubMed]

6. World Health Organisation. Report of the SAGE Working Group on Vaccine Hesitancy. 2014. Available online: https://www. who.int/immunization/sage/meetings/2014/october/1_Report_WORKING_GROUP_vaccine_hesitancy_final.pdf (accessed on 27 March 2021).

7. Wellcome. Wellcome Global Monitor 2018. Available online: https://wellcome.ac.uk/reports/wellcome-global-monitor/2018 (accessed on 27 March 2021).

8. Bhopal, S.; Nielsen, M. Vaccine hesitancy in low- and middle-income countries: Potential implications for the COVID-19 response. Arch. Dis. Child. 2021, 106, 113-114. [CrossRef]

9. World Bank Blogs. New Country Classifications by Income Level: 2019-2020. 1 July 2019. Available online: https://blogs. worldbank.org/opendata/new-country-classifications-income-level-2019-2020 (accessed on 24 March 2021).

10. Arce, J.S.S.; Warren, S.S.; Meriggi, N.F.; Scacco, A.; McMurry, N.; Voors, M.; Syunyaev, G.; Malik, A.A.; Aboutajdine, S.; Adeojo, O.; et al. COVID-19 vaccine acceptance and hesitancy in low- and middle-income countries. Nat. Med. 2021, 1-10. [CrossRef]

11. Sallam, M. COVID-19 Vaccine Hesitancy Worldwide: A Concise Systematic Review of Vaccine Acceptance Rates. Vaccines 2021, 9, 160. [CrossRef]

12. Tricco, A.C.; Lillie, E.; Zarin, W. PRISMA Extension for Scoping Reviews (PRISMA-ScR): Checklist and Explanation. Ann. Intern. Med. 2018, 169, 467-473. [CrossRef] [PubMed]

13. Lin, C.; Tu, P.; Beitsch, L.M. Confidence and Receptivity for COVID-19 Vaccines: A Rapid Systematic Review. Vaccines 2020, 9, 16. [CrossRef]

14. Smith, L.E.; Amlôt, R.; Weinman, J.A.; Yiend, J.; Rubin, G.J. A systematic review of factors affecting vaccine uptake in young children. Vaccine 2017, 35, 6059-6069. [CrossRef] [PubMed]

15. Dror, A.A.; Eisenbach, N.; Taiber, S.; Morozov, N.G.; Mizrachi, M.; Zigron, A.; Srouji, S.; Sela, E. Vaccine hesitancy: The next challenge in the fight against COVID-19. Eur. J. Epidemiol. 2020, 35, 775-779. [CrossRef]

16. Anderson, R.M.; Vegvari, C.; Truscott, J.; Collyer, B.S. Challenges in creating herd immunity to SARS-CoV-2 infection by mass vaccination. Lancet 2020, 396, 1614-1616. [CrossRef]

17. Larson, H.J.; Jarrett, C.; Eckersberger, E.; Smith, D.M.D.; Paterson, P. Understanding Vaccine Hesitancy around Vaccines and Vaccination from a Global Perspective: A Systematic Review of Published Literature, 2007-2012. Vaccine 2014, 32, 2150-2159. [CrossRef] [PubMed]

18. Klein, J.K.; Middleman, A.B.; Quinn, J.R. 10. COVID-19 Impact on Parent/Young Adult Attitudes and Beliefs Toward Vaccines for Adolescents and Young Adults. J. Adolesc. Health 2021, 68, S6. [CrossRef]

19. AlHajri, B.; Alenezi, D.; Alfouzan, H.; Altamimi, S.; Alzalzalah, S.; Almansouri, W.; Alqudeimat, Y.; Almokhaizeem, Z.; Ziyab, A.H. Willingness of parents to vaccinate their children against influenza and the novel coronavirus disease-2019. J. Pediatr. 2021, 231, 298-299. [CrossRef]

20. Alabdulla, M.; Reagu, S.M.; Al-Khal, A.; Elzain, M.; Jones, R.M. COVID-19 vaccine hesitancy and attitudes in Qatar: A national cross-sectional survey of a migrant-majority population. Influenza Other Respir. Viruses 2021, 15, 361-370. [CrossRef] [PubMed]

21. Beesley, R.P.; Costello, W.; Angevare, S.P.; Wouters, C.; Wulffraat, N.; Uziel, Y. Survey of adult and paediatric rheumatology patients suggests information about COVID-19 vaccination will aid uptake. Rheumatology 2021, 60, 3474-3475. [CrossRef] [PubMed]

22. Pogue, K.; Jensen, J.L.; Stancil, C.K.; Ferguson, D.G.; Hughes, S.J.; Mello, E.J.; Burgess, R.; Berges, B.K.; Quaye, A.; Poole, B.D. Influences on Attitudes Regarding Potential COVID-19 Vaccination in the United States. Vaccines 2020, 8, 582. [CrossRef] [PubMed]

23. Bell, S.; Clarke, R.; Mounier-Jack, S.; Walker, J.L.; Paterson, P. Parents' and guardians' views on the acceptability of a future COVID-19 vaccine: A multi-methods study in England. Vaccine 2020, 38, 7789-7798. [CrossRef]

24. Goldman, R.D.; Marneni, S.R.; Seiler, M.; Brown, J.C.; Klein, E.J.; Cotanda, C.P.; Gelernter, R.; Yan, T.D.; Hoeffe, J.; Davis, A.L.; et al. Caregivers' Willingness to Accept Expedited Vaccine Research During the COVID-19 Pandemic: A Cross-sectional Survey. Clin. Ther. 2020, 42, 2124-2133. [CrossRef] 
25. Goldman, R.D.; Yan, T.D.; Seiler, M.; Cotanda, C.P.; Brown, J.C.; Klein, E.J.; Hoeffe, J.; Gelernter, R.; Hall, J.E.; Davis, A.L.; et al. Caregiver willingness to vaccinate their children against COVID-19: Cross sectional survey. Vaccine 2020, 38, 7668-7673. [CrossRef]

26. Benham, J.L.; Lang, R.; Burns, K.K.; MacKean, G.; Léveillé, T.; McCormack, B.; Sheikh, H.; Fullerton, M.M.; Tang, T.; Boucher, J.-C.; et al. Attitudes, current behaviours and barriers to public health measures that reduce COVID-19 transmission: A qualitative study to inform public health messaging. PLoS ONE 2021, 16, e0246941. [CrossRef]

27. Momplaisir, F.; Haynes, N.; Nkwihoreze, H.; Nelson, M.; Werner, R.M.; Jemmott, J. Understanding Drivers of COVID-19 Vaccine Hesitancy Among Blacks. Clin. Infect. Dis. Off. Publ. Infect. Dis. Soc. Am. 2021. [CrossRef]

28. Peretti-Watel, P.; Seror, V.; Cortaredona, S.; Launay, O.; Raude, J.; Verger, P.; Fressard, L.; Beck, F.; Legleye, S.; L’Haridon, O.; et al. A future vaccination campaign against COVID-19 at risk of vaccine hesitancy and politicisation. Lancet Infect. Dis. 2020, 20, 769-770. [CrossRef]

29. Attwell, K.; Lake, J.; Sneddon, J.; Gerrans, P.; Blyth, C.; Lee, J. Converting the maybes: Crucial for a successful COVID-19 vaccination strategy. PLoS ONE 2021, 16, e0245907. [CrossRef]

30. Barrière, J.; Gal, J.; Hoch, B.; Cassuto, O.; Leysalle, A.; Chamorey, E.; Borchiellini, D. Acceptance of SARS-CoV-2 vaccination among French patients with cancer: A cross-sectional survey. Ann. Oncol. 2021, 32, 673-674. [CrossRef]

31. Callaghan, T.; Moghtaderi, A.; Lueck, J.A.; Hotez, P.; Strych, U.; Dor, A.; Fowler, E.F.; Motta, M. Correlates and disparities of intention to vaccinate against COVID-19. Soc. Sci. Med. 2021, 272, 113638. [CrossRef]

32. Detoc, M.; Bruel, S.; Frappe, P.; Tardy, B.; Botelho-Nevers, E.; Gagneux-Brunon, A. Intention to participate in a COVID-19 vaccine clinical trial and to get vaccinated against COVID-19 in France during the pandemic. Vaccine 2020, 38, 7002-7006. [CrossRef]

33. Feleszko, W.; Lewulis, P.; Czarnecki, A.; Waszkiewicz, P. Flattening the Curve of COVID-19 Vaccine Rejection-An International Overview. Vaccines 2021, 9, 44. [CrossRef]

34. Freeman, D.; Loe, B.S.; Chadwick, A.; Vaccari, C.; Waite, F.; Rosebrock, L.; Jenner, L.; Petit, A.; Lewandowsky, S.; Vanderslott, S.; et al. COVID-19 vaccine hesitancy in the UK: The Oxford coronavirus explanations, attitudes, and narratives survey (Oceans) II. Psychol. Med. 2020, 1-15. [CrossRef]

35. Gagneux-Brunon, A.; Detoc, M.; Bruel, S.; Tardy, B.; Rozaire, O.; Frappe, P.; Botelho-Nevers, E. Intention to get vaccinations against COVID-19 in French healthcare workers during the first pandemic wave: A cross-sectional survey. J. Hosp. Infect. 2021, 108, 168-173. [CrossRef] [PubMed]

36. Grüner, S.; Krüger, F. The intention to be vaccinated against COVID-19: Stated preferences before vaccines were available. Appl. Econ. Lett. 2020, 1-5. [CrossRef]

37. Hursh, S.R.; Strickland, J.C.; Schwartz, L.P.; Reed, D.D. Quantifying the Impact of Public Perceptions on Vaccine Acceptance Using Behavioral Economics. Front. Public Health 2020, 8, 608852. [CrossRef]

38. Karlsson, L.C.; Soveri, A.; Lewandowsky, S.; Karlsson, L.; Karlsson, H.; Nolvi, S.; Karukivi, M.; Lindfelt, M.; Antfolk, J. Fearing the disease or the vaccine: The case of COVID-19. Personal. Individ. Differ. 2021, 172, 110590. [CrossRef]

39. Khubchandani, J.; Sharma, S.; Price, J.H.; Wiblishauser, M.J.; Sharma, M.; Webb, F.J. COVID-19 Vaccination Hesitancy in the United States: A Rapid National Assessment. J. Community Health 2021, 46, 270-277. [CrossRef]

40. Kociolek, L.K.; Elhadary, J.; Jhaveri, R.; Patel, A.B.; Stahulak, B.; Cartland, J. Coronavirus disease 2019 vaccine hesitancy among children's hospital staff: A single-center survey. Infect. Control Hosp. Epidemiol. 2021, 2021, 1-3. [CrossRef]

41. Kreps, S.; Prasad, S.; Brownstein, J.S.; Hswen, Y.; Garibaldi, B.T.; Zhang, B.; Kriner, D.L. Factors Associated With US Adults' Likelihood of Accepting COVID-19 Vaccination. JAMA Netw. Open 2020, 3, e2025594. [CrossRef] [PubMed]

42. Kuter, B.J.; Browne, S.; Momplaisir, F.M.; Feemster, K.A.; Shen, A.K.; Green-McKenzie, J.; Faig, W.; Offit, P.A. Perspectives on the receipt of a COVID-19 vaccine: A survey of employees in two large hospitals in Philadelphia. Vaccine 2021, 39, 1693-1700. [CrossRef] [PubMed]

43. Latkin, C.A.; Dayton, L.; Yi, G.; Colon, B.; Kong, X. Mask usage, social distancing, racial, and gender correlates of COVID-19 vaccine intentions among adults in the US. PLoS ONE 2021, 16, e0246970. [CrossRef] [PubMed]

44. Malik, A.A.; McFadden, S.M.; Elharake, J.; Omer, S.B. Determinants of COVID-19 vaccine acceptance in the US. EClinicalMedicine 2020, 26, 100495. [CrossRef]

45. Manning, M.L.; Gerolamo, A.M.; Marino, M.A.; Hanson-Zalot, M.E.; Pogorzelska-Maziarz, M. COVID-19 vaccination readiness among nurse faculty and student nurses. Nurs. Outlook 2021. [CrossRef]

46. Nguyen, K.H.; Srivastav, A.; Razzaghi, H.; Williams, W.; Lindley, M.C.; Jorgensen, C.; Abad, N.; Singleton, J.A. COVID-19 Vaccination Intent, Perceptions, and Reasons for not Vaccinating among Groups Prioritized for Early Vaccination-United States, September And December 2020. 2021. Available online: https://www.cdc.gov/vaccines/imz-managers/coverage/ adultvaxview / pubs-resources /COVID-online-report2020.html (accessed on 26 January 2021).

47. Priori, R.; Pellegrino, G.; Colafrancesco, S.; Alessandri, C.; Ceccarelli, F.; Di Franco, M.; Riccieri, V.; Scrivo, R.; Scavalli, A.S.; Spinelli, F.R.; et al. SARS-CoV-2 vaccine hesitancy among patients with rheumatic and musculoskeletal diseases: A message for rheumatologists. Ann. Rheum. Dis. 2021, 80, 953-954. [CrossRef]

48. Reiter, P.L.; Pennell, M.L.; Katz, M.L. Acceptability of a COVID-19 vaccine among adults in the United States: How many people would get vaccinated? Vaccine 2020, 38, 6500-6507. [CrossRef]

49. Ruiz, J.B.; Bell, R.A. Predictors of intention to vaccinate against COVID-19: Results of a nationwide survey. Vaccine 2021, 39, 1080-1086. [CrossRef] 
50. Schmelz, K. Enforcement may crowd out voluntary support for COVID-19 policies, especially where trust in government is weak and in a liberal society. Proc. Natl. Acad. Sci. USA 2021, 118, e2016385118. [CrossRef] [PubMed]

51. Schwarzinger, M.; Watson, V.; Arwidson, P.; Alla, F.; Luchini, S. COVID-19 vaccine hesitancy in a representative working-age population in France: A survey experiment based on vaccine characteristics. Lancet Public Health 2021, 6, e210-e221. [CrossRef]

52. Shaw, J.; Stewart, T.; Anderson, K.B.; Hanley, S.; Thomas, S.J.; Salmon, D.A.; Morley, C. Assessment of U.S. Health Care Personnel (HCP) Attitudes towards COVID-19 Vaccination in a large University Health Care System. Clinical Infectious Diseases: An Official Publication of the Infectious Diseases Society of America. 2021. Available online: https://academic.oup.com/cid/ advance-article/doi/10.1093/cid/ciab054/6118651 (accessed on 21 March 2021).

53. Shekhar, R.; Sheikh, A.; Upadhyay, S.; Singh, M.; Kottewar, S.; Mir, H.; Barrett, E.; Pal, S. COVID-19 Vaccine Acceptance among Health Care Workers in the United States. Vaccines 2021, 9, 119. [CrossRef] [PubMed]

54. Sherman, S.M.; Smith, L.E.; Sim, J.; Amlôt, R.; Cutts, M.; Dasch, H.; Rubin, G.J.; Sevdalis, N. COVID-19 vaccination intention in the UK: Results from the COVID-19 vaccination acceptability study (CoVAccS), a nationally representative cross-sectional survey. Hum. Vaccines Immunother. 2021, 17, 1612-1621. [CrossRef]

55. Szilagyi, P.G.; Thomas, K.; Shah, M.D.; Vizueta, N.; Cui, Y.; Vangala, S.; Kapteyn, A. National Trends in the US Public's Likelihood of Getting a COVID-19 Vaccine-1 April to 8 December 2020. JAMA 2021, 325, 396. [CrossRef]

56. Unroe, K.T.; Evans, R.; Weaver, L.; Rusyniak, D.; Blackburn, J. Willingness of Long-Term Care Staff to Receive a COVID-19 Vaccine: A Single State Survey. J. Am. Geriatr. Soc. 2021, 69, 593-599. [CrossRef]

57. Verger, P.; Scronias, D.; Dauby, N.; Adedzi, K.A.; Gobert, C.; Bergeat, M.; Gagneur, A.; Dubé, E. Attitudes of healthcare workers towards COVID-19 vaccination: A survey in France and French-speaking parts of Belgium and Canada, 2020. Eurosurveillance 2021, 26, 2002047. [CrossRef]

58. Wang, K.; Wong, E.L.Y.; Ho, K.F.; Cheung, A.W.L.; Chan, E.Y.Y.; Yeoh, E.K.; Wong, S.Y.S. Intention of nurses to accept coronavirus disease 2019 vaccination and change of intention to accept seasonal influenza vaccination during the coronavirus disease 2019 pandemic: A cross-sectional survey. Vaccine 2020, 38, 7049-7056. [CrossRef] [PubMed]

59. Wang, K.; Wong, E.L.Y.; Ho, K.-F.; Cheung, A.W.L.; Yau, P.S.Y.; Dong, D.; Wong, S.Y.S.; Yeoh, E.-K. Change of willingness to accept COVID-19 vaccine and reasons of vaccine hesitancy of working people at different waves of local epidemic in Hong Kong, China: Repeated cross-sectional surveys. Vaccines 2021, 9, 62. [CrossRef]

60. Ward, J.K.; Alleaume, C.; Peretti-Watel, P.; Seror, V.; Cortaredona, S.; Launay, O.; Raude, J.; Verger, P.; Beck, F.; Legleye, S.; et al. The French public's attitudes to a future COVID-19 vaccine: The politicization of a public health issue. Soc. Sci. Med. 2020, 265, 113414. [CrossRef] [PubMed]

61. Yoda, T.; Katsuyama, H. Willingness to Receive COVID-19 Vaccination in Japan. Vaccines 2021, 9, 48. [CrossRef]

62. Al-Mohaithef, M.; Padhi, B.K. Determinants of COVID-19 Vaccine Acceptance in Saudi Arabia: A Web-Based National Survey. J. Multidiscip. Health 2020, 13, 1657-1663. [CrossRef] [PubMed]

63. Caban-Martinez, A.J.; Silvera, C.A.; Santiago, K.M.; Louzado-Feliciano, P.; Burgess, J.L.; Smith, D.L.; Jahnke, S.; Horn, G.P.; Graber, J.M. COVID-19 Vaccine Acceptability among U.S. Firefighters and Emergency Medical Services Workers: A Cross-Sectional Study. J. Occup. Environ. Med. 2021, 63, 369. [CrossRef] [PubMed]

64. Dodd, R.H.; Cvejic, E.; Bonner, C.; Pickles, K.; McCaffery, K.J.; Ayre, J.; Batcup, C.; Copp, T.; Cornell, S.; Dakin, T.; et al. Willingness to vaccinate against COVID-19 in Australia. Lancet Infect. Dis. 2021, 21, 318-319. [CrossRef]

65. Faasse, K.; Newby, J. Public Perceptions of COVID-19 in Australia: Perceived Risk, Knowledge, Health-Protective Behaviors, and Vaccine Intentions. Front. Psychol. 2020, 11, 551004. [CrossRef]

66. Fisher, K.A.; Bloomstone, S.J.; Walder, J.; Crawford, S.; Fouayzi, H.; Mazor, K.M. Attitudes toward a potential SARS-CoV-2 vaccine: A survey of US adults. Ann. Intern. Med. 2020, 173, 964-973. [CrossRef]

67. Gadoth, A.; Halbrook, M.; Martin-Blais, R.; Gray, A.; Tobin, N.H.; Ferbas, K.G.; Aldrovandi, G.M.; Rimoin, A.W. Cross-sectional assessment of COVID-19 vaccine acceptance among health care workers in Los Angeles. Ann. Intern. Med. 2021. [CrossRef]

68. Head, K.J.; Kasting, M.L.; Sturm, L.A.; Hartsock, J.A.; Zimet, G.D. A National Survey Assessing SARS-CoV-2 Vaccination Intentions: Implications for Future Public Health Commu-nication Efforts. Sci. Commun. 2020, 42, 698-723. [CrossRef]

69. La Vecchia, C.; Negri, E.; Alicandro, G.; Scarpino, V. Attitudes towards influenza vaccine and a potential COVID-19 vaccine in Italy and differences across occupational groups, September 2020. Med. Lav. 2020, 111, 445-448.

70. McPhedran, R.; Toombs, B. Efficacy or delivery? An online Discrete Choice Experiment to explore preferences for COVID-19 vaccines in the UK. Econ. Lett. 2021, 200, 109747. [CrossRef]

71. Mercadante, A.R.; Law, A.V. Will they, or Won't they? Examining patients' vaccine intention for flu and COVID-19 using the Health Belief Model. Res. Soc. Adm. Pharm. 2021, 17, 1596-1605. [CrossRef]

72. Romer, D.; Jamieson, K.H. Conspiracy theories as barriers to controlling the spread of COVID-19 in the U.S. Soc. Sci. Med. 2020, 263, 113356. [CrossRef] [PubMed]

73. Seale, H.; Heywood, A.E.; Leask, J.; Sheel, M.; Durrheim, D.N.; Bolsewicz, K.; Kaur, R. Examining Australian public perceptions and behaviors towards a future COVID-19 vaccine. BMC Infect. Dis. 2021, 21, 1-9. [CrossRef] [PubMed]

74. Amin, D.P.; Palter, J.S. COVID-19 vaccination hesitancy among healthcare personnel in the emergency department de-serves con-tinued attention. Am. J. Emerg. Med. 2021. [CrossRef] [PubMed]

75. Largent, E.A.; Persad, G.; Sangenito, S.; Glickman, A.; Boyle, C.; Emanuel, E.J. US Public Attitudes Toward COVID-19 Vaccine Mandates. JAMA Netw. Open 2020, 3, e2033324. [CrossRef] [PubMed] 
76. Olagoke, A.A.; Olagoke, O.; Hughes, A.M. Intention to Vaccinate Against the Novel 2019 Coronavirus Disease: The Role of Health Locus of Control and Religiosity. J. Relig. Health 2021, 60, 65-80. [CrossRef]

77. KFF/The Undefeated Survey on Race and Health. 2020. Available online: https://www.kff.org/racial-equity-and-health-policy/ report/kff-the-undefeated-survey-on-race-and-health/ (accessed on 1 May 2021).

78. Alley, S.J.; Stanton, R.; Browne, M.; To, Q.G.; Khalesi, S.; Williams, S.L.; Thwaite, T.L.; Fenning, A.S.; Vandelanotte, C. As the Pandemic Progresses, How Does Willingness to Vaccinate against COVID-19 Evolve? Int. J. Environ. Res. Public Health 2021, 18, 797. [CrossRef]

79. Bogart, L.M.; Ojikutu, B.O.; Tyagi, K.; Klein, D.J.; Mutchler, M.G.; Dong, L.; Lawrence, S.J.; Thomas, D.R.; Kellman, S. COVID-19 Related Medical Mistrust, Health Impacts, and Potential Vaccine Hesitancy Among Black Americans Living With HIV. JAIDS J. Acquir. Immune Defic. Syndr. 2021, 86, 200-207. [CrossRef]

80. Campochiaro, C.; Trignani, G.; Tomelleri, A.; Cascinu, S.; Dagna, L. Potential acceptance of COVID-19 vaccine in rheumatological patients: A monocentric comparative survey. Ann. Rheum. Dis. 2021, 80, 816-817. [CrossRef]

81. Ehde, D.M.; Roberts, M.K.; Herring, T.E.; Alschuler, K.N. Willingness to obtain COVID-19 vaccination in adults with multiple sclerosis in the United States. Mult. Scler. Relat. Disord. 2021, 49, 102788. [CrossRef]

82. Niankara, I.; Muqattash, R.; Niankara, A.; Traoret, R.I. COVID-19 Vaccine Development in a Quadruple Helix Innovation System: Uncovering the Preferences of the Fourth Helix in the UAE. J. Open Innov. Technol. Mark. Complex. 2020, 6, 132. [CrossRef]

83. Williams, L.; Flowers, P.; McLeod, J.; Young, D.; Rollins, L.; The Catalyst Project Team. Social Patterning and Stability of Intention to Accept a COVID-19 Vaccine in Scotland: Will Those Most at Risk Accept a Vaccine? Vaccines 2021, 9, 17. [CrossRef]

84. Murphy, J.; Vallières, F.; Bentall, R.P.; Shevlin, M.; McBride, O.; Hartman, T.K.; McKay, R.; Bennett, K.; Mason, L.; Gibson-Miller J.; et al. Psychological characteristics associated with COVID-19 vaccine hesitancy and resistance in Ireland and the United Kingdom. Nat. Commun. 2021, 12, 1-15. [CrossRef]

85. Guidry, J.P.; Laestadius, L.I.; Vraga, E.K.; Miller, C.A.; Perrin, P.B.; Burton, C.W.; Ryan, M.; Fuemmeler, B.F.; Carlyle, K.E. Willingness to get the COVID-19 vaccine with and without emergency use authorization. Am. J. Infect. Control 2021, 49, 137-142. [CrossRef]

86. Jeffs, E.; Lucas, N.; Walls, T. CoVID-19: Parent and caregiver concerns about reopening New Zealand schools. J. Paediatr. Child Health 2021, 57, 403-408. [CrossRef] [PubMed]

87. Muqattash, R.; Niankara, I.; Traoret, R.I. Survey data for COVID-19 vaccine preference analysis in the United Arab Emirates. Data Brief 2020, 33, 106446. [CrossRef] [PubMed]

88. Underschultz, J.G.; Barber, P.; Richard, D.; Hillier, T. What drives resistance to public health measures in Canada's COVID-19 pandemic? An online survey of Canadians' knowledge, attitudes, and practices. Univ. Tor. Med. J. 2021, 98, 35-40.

89. Hoke, A.M.; Keller, C.M.; Calo, W.A.; Sekhar, D.L.; Lehman, E.B.; Kraschnewski, J.L. School Nurse Perspectives on COVID-19. J. Sch. Nurs. 2021, 37, 292-297. [CrossRef]

90. Taylor, S.; Landry, C.A.; Paluszek, M.M.; Groenewoud, R.; Rachor, G.S.; Asmundson, G.J. A proactive approach for managing COVID-19: The importance of understanding the motivational roots of vaccination hesitancy for SARS-CoV2. Front. Psychol. 2020, 11, 2890. [CrossRef]

91. Wong, M.C.; Wong, E.L.; Huang, J.; Cheung, A.W.; Law, K.; Chong, M.K.; Ng, R.W.; Lai, C.K.; Boon, S.S.; Lau, J.T.; et al. Acceptance of the COVID-19 vaccine based on the health belief model: A population-based survey in Hong Kong. Vaccine 2021, 39, 1148-1156. [CrossRef]

92. Kwok, K.O.; Li, K.-K.; Wei, W.I.; Tang, A.; Wong, S.Y.S.; Lee, S.S. Influenza vaccine uptake, COVID-19 vaccination intention and vaccine hesitancy among nurses: A survey. Int. J. Nurs. Stud. 2021, 114, 103854. [CrossRef] [PubMed]

93. Sprengholz, P.; Eitze, S.; Felgendreff, L.; Korn, L.; Betsch, C. Money is not everything: Experimental evidence that payments do not increase willingness to be vaccinated against COVID-19. J. Med. Ethics 2021, 47, 547-548. [CrossRef] [PubMed]

94. Bokemper, S.E.; Huber, G.A.; Gerber, A.S.; James, E.K.; Omer, S.B. Timing of COVID-19 vaccine approval and endorsement by public figures. Vaccine 2021, 39, 825-829. [CrossRef] [PubMed]

95. Lucia, V.C.; Kelekar, A.; Afonso, N.M. COVID-19 vaccine hesitancy among medical students. J. Public Health 2020, fdaa230. [CrossRef] [PubMed]

96. Prati, G. Intention to receive a vaccine against SARS-CoV-2 in Italy and its association with trust, worry and beliefs about the origin of the virus. Health Educ. Res. 2020, 35, 505-511. [CrossRef] [PubMed]

97. Williams, L.; Gallant, A.J.; Rasmussen, S.; Nicholls, L.A.B.; Cogan, N.; Deakin, K.; Young, D.; Flowers, P. Towards intervention development to increase the uptake of COVID-19 vaccination among those at high risk: Outlining evidence-based and theoretically informed future intervention content. Br. J. Health Psychol. 2020, 25, 1039-1054. [CrossRef] [PubMed]

98. Chu, H.; Liu, S. Integrating health behavior theories to predict American's intention to receive a COVID-19 vaccine. Patient Educ. Couns. 2021, 104, 1878-1886. [CrossRef]

99. Palamenghi, L.; Barello, S.; Boccia, S.; Graffigna, G. Mistrust in biomedical research and vaccine hesitancy: The forefront challenge in the battle against COVID-19 in Italy. Eur. J. Epidemiol. 2020, 35, 785-788. [CrossRef]

100. Kourlaba, G.; Kourkouni, E.; Maistreli, S.; Tsopela, C.-G.; Molocha, N.-M.; Triantafyllou, C.; Koniordou, M.; Kopsidas, I.; Chorianopoulou, E.; Maroudi-Manta, S.; et al. Willingness of Greek general population to get a COVID-19 vaccine. Glob. Health Res. Policy 2021, 6, 1-10. [CrossRef] [PubMed] 
101. Barello, S.; Nania, T.; Dellafiore, F.; Graffigna, G.; Caruso, R. 'Vaccine hesitancy' among university students in Italy during the COVID-19 pandemic. Eur. J. Epidemiol. 2020, 35, 781-783. [CrossRef] [PubMed]

102. Jung, H.; Albarracín, D. Concerns for others increases the likelihood of vaccination against influenza and COVID-19 more in sparsely rather than densely populated areas. Proc. Natl. Acad. Sci. USA 2021, 118, 118. [CrossRef] [PubMed]

103. Caserotti, M.; Girardi, P.; Rubaltelli, E.; Tasso, A.; Lotto, L.; Gavaruzzi, T. Associations of COVID-19 risk perception with vaccine hesitancy over time for Italian residents. Soc. Sci. Med. 2021, 272, 113688. [CrossRef] [PubMed]

104. Graffigna, G.; Palamenghi, L.; Boccia, S.; Barello, S. Relationship between Citizens' Health Engagement and Intention to Take the COVID-19 Vaccine in Italy: A Me-diation Analysis. Vaccines 2020, 8, 576. [CrossRef] [PubMed]

105. Freeman, D.; Waite, F.; Rosebrock, L.; Petit, A.; Causier, C.; East, A.; Jenner, L.; Teale, A.-L.; Carr, L.; Mulhall, S.; et al. Coronavirus conspiracy beliefs, mistrust, and compliance with government guidelines in England. Psychol. Med. 2020, 1-13. [CrossRef] [PubMed]

106. Hughes, S.; Machan, L. It's a conspiracy: Covid-19 conspiracies link to psychopathy, Machiavellianism and collective narcissism. Pers. Individ. Differ. 2021, 171, 110559. [CrossRef]

107. Neumann-Böhme, S.; Varghese, N.E.; Sabat, I.; Barros, P.P.; Brouwer, W.; Van Exel, J.; Schreyögg, J.; Stargardt, T. Once we have it, will we use it? A European survey on willingness to be vaccinated against COVID-19. Eur. J. Health Econ. 2020, 21, 977-982. [CrossRef]

108. Szmyd, B.; Bartoszek, A.; Karuga, F.F.; Staniecka, K.; Błaszczyk, M.; Radek, M. Medical students and SARS-CoV-2 vaccination: Attitude and behaviors. Vaccines 2021, 9, 128. [CrossRef] [PubMed]

109. Loomba, S.; de Figueiredo, A.; Piatek, S.J.; de Graaf, K.; Larson, H.J. Measuring the impact of COVID-19 vaccine misinformation on vaccination intent in the UK and USA. Nat. Hum. Behav. 2021, 5, 337-348. [CrossRef]

110. Borriello, A.; Master, D.; Pellegrini, A.; Rose, J.M. Preferences for a COVID-19 vaccine in Australia. Vaccine 2021, $39,473-479$. [CrossRef]

111. Motta, M. Can a COVID-19 vaccine live up to Americans' expectations? A conjoint analysis of how vaccine characteristics influence vaccination intentions. Soc. Sci. Med. 2021, 272, 113642. [CrossRef] [PubMed]

112. Boulton, M.L.; Carlson, B.F.; Power, L.E.; Wagner, A.L. Socioeconomic factors associated with full childhood vaccination in Bangladesh, 2014. Int. J. Infect. Dis. 2018, 69, 35-40. [CrossRef] [PubMed]

113. Wiysonge, C.S.; Uthman, O.A.; Ndumbe, P.M.; Hussey, G.D. Individual and Contextual Factors Associated with Low Childhood Immunisation Coverage in Sub-Saharan Africa: A Multilevel Analysis. PLoS ONE 2012, 7, e37905. [CrossRef]

114. Crocker-Buque, T.; Mindra, G.; Duncan, R.; Mounier-Jack, S. Immunization, urbanization and slums-A systematic review of factors and interventions. BMC Public Health 2017, 17, 1-16. [CrossRef] [PubMed]

115. Dror, A.A.; Daoud, A.; Morozov, N.G.; Layous, E.; Eisenbach, N.; Mizrachi, M.; Rayan, D.; Bader, A.; Francis, S.; Kaykov, E.; et al. Vaccine hesitancy due to vaccine country of origin, vaccine technology, and certification. Eur. J. Epidemiol. 2021, $2021,1-6$. [CrossRef]

116. Richie, H.; Ortiz-Ospina, E.; Beltekian, D.; Methieu, E.; Hasell, J.; Macdonald, B.; Giattino, C.; Appel, C.; Rodes-Guirao, L.; Roser, M. Coronavirus (COVID-19) Vaccinations Statistics and Research. 2021. Available online: https://ourworldindata.org/covidvaccinations (accessed on 16 May 2021).

117. Sallam, M.; Dababseh, D.; Yaseen, A.; Al-Haidar, A.; Taim, D.; Eid, H.; Ababneh, N.A.; Bakri, F.G.; Mahafzah, A. COVID-19 misinformation: Mere harmless delusions or much more? A knowledge and attitude cross-sectional study among the general public residing in Jordan. PLoS ONE 2020, 15, e0243264. [CrossRef]

118. Mohan, S.; Reagu, S.; Lindow, S.; Alabdulla, M. COVID-19 vaccine hesitancy in perinatal women: A cross sectional survey. J. Périnat. Med. 2021, 49, 678-685. [CrossRef]

119. Editorial, A.B. Why Millennials and Gen. Z Aren't Getting Vaccinated-and What to Do about It. Available online: https: //www.advisory.com/en/daily-briefing/2021/04/26/vaccine-hesitancy (accessed on 16 May 2021).

120. Bogart, L.M.; Dong, L.; Gandhi, P.; Ryan, S.; Smith, T.L.; Klein, D.J.; Fuller, L.-A.; Ojikutu, B.O. What Contributes to COVID-19 Vaccine Hesitancy in Black Communities, and How Can It Be Addressed? RAND Corporation: Santa Monica, CA, USA, 2021.

121. Edwards, B.; Biddle, N.; Gray, M.; Sollis, K. COVID-19 vaccine hesitancy and resistance: Correlates in a nationally representative longitudinal survey of the Australian population. PLoS ONE 2021, 16, e0248892. [CrossRef]

122. Shore, D.A. Communicating in times of uncertainty: The need for trust. J. Health Commun. 2003, 8, 13-14. [CrossRef] [PubMed]

123. Wouters, O.J.; Shadlen, K.C.; Salcher-Konrad, M.; Pollard, A.J.; Larson, H.J.; Teerawattananon, Y.; Jit, M. Challenges in ensuring global access to COVID-19 vaccines: Production, affordability, allocation, and deployment. Lancet 2021, 397, 1023-1034. [CrossRef]

124. Mathieu, E.; Ritchie, H.; Ortiz-Ospina, E.; Roser, M.; Hasell, J.; Appel, C.; Giattino, C. A global database of COVID-19 vaccinations. Nat. Hum. Behav. 2021, 1-7. [CrossRef]

125. Bartsch, S.M.; O'Shea, K.J.; Ferguson, M.C.; Bottazzi, M.E.; Wedlock, P.T.; Strych, U.; McKinnell, J.A.; Siegmund, S.S.; Cox, S.N.; Hotez, P.J.; et al. Vaccine efficacy needed for a COVID-19 coronavirus vaccine to prevent or stop an epidemic as the sole intervention. Am. J. Prev. Med. 2020, 59, 493-503. [CrossRef]

126. Morgul, E.; Bener, A.; Atak, M.; Akyel, S.; Aktaş, S.; Bhugra, D.; Ventriglio, A.; Jordan, T.R. COVID-19 pandemic and psychological fatigue in Turkey. Int. J. Soc. Psychiatry 2021, 67, 128-135. [CrossRef]

127. Webber-Ritchey, K.J.; Simonovich, S.D.; Spurlark, R.S. COVID-19: Qualitative Research With Vulnerable Populations. Nurs. Sci. Q. 2021, 34, 13-19. [CrossRef] [PubMed] 
128. Tremblay, S.; Castiglione, S.; Audet, L.-A.; Desmarais, M.; Horace, M.; Peláez, S. Conducting Qualitative Research to Respond to COVID-19 Challenges: Reflections for the Present and Beyond. Int. J. Qual. Methods 2021, 20. [CrossRef]

129. Wright, K.B. Researching Internet-Based Populations: Advantages and Disadvantages of Online Survey Research, Online Question-naire Authoring Software Packages, and Web Survey Services. J. Comput. Mediat. Commun. 2017, 10, JCMC1034. [CrossRef]

130. Eysenbach, G. Improving the quality of Web surveys: The Checklist for Reporting Results of Internet E-Surveys (CHER-RIES). J. Med. Internet Res. 2004, 6, e34. [CrossRef]

131. McCaffery, K.J.; Dodd, R.H.; Cvejic, E.; Ayrek, J.; Isautier, J.M.; Copp, T.; Bonner, C.; Pickles, K.; Nickel, B.; Dakin, T.; et al. Health literacy and disparities in COVID-19-related knowledge, attitudes, beliefs and behaviours in Australia. Public Health Res. Pract. 2020, 30, 30342012. [CrossRef] 